\title{
Yampa River-Colorado River Drainage Divide Origin Determined from Topographic Map Evidence, Southern Routt County, Colorado, USA
}

\author{
Eric Clausen (10) \\ Independent Investigator, Jenkintown, PA, USA \\ Email: eric2clausen@gmail.com
}

How to cite this paper: Clausen, E. (2021) Yampa River-Colorado River Drainage Divide Origin Determined from Topographic Map Evidence, Southern Routt County, Colorado, USA. Open Journal of Geology, 11, 319-339.

https://doi.org/10.4236/ojg.2021.118017

Received: July 2, 2021

Accepted: August 7, 2021

Published: August 10, 2021

Copyright $\odot 2021$ by author(s) and Scientific Research Publishing Inc. This work is licensed under the Creative Commons Attribution International License (CC BY 4.0).

http://creativecommons.org/licenses/by/4.0/

(c) (i) Open Access

\begin{abstract}
Detailed topographic map evidence and a new Cenozoic geologic and glacial history paradigm are used to determine the previously unexplained Yampa River-Colorado River drainage divide origin. The Yampa River now flows in a north direction away from the Colorado River (between the Park Range to the east and the Flat Tops region to the west) before turning in a west direction to reach the Unita Mountains where it joins the south-oriented Green River, which eventually joins the southwest-oriented Colorado River. Topographic maps show the Yampa-Colorado River drainage divide is asymmetric with steeper slopes leading to the Colorado River, barbed (south-oriented) tributaries leading to north-oriented Yampa River headwaters (especially near the Yampa River turn to the west), and evidence of a large north-to-south oriented diverging and converging channel complex that preceded present-day drainage routes. Map evidence is interpreted to mean massive south-oriented floods flowed through what are now north-oriented Yampa River headwaters valleys and that headward erosion of a deep west-oriented valley beheaded and reversed those south-oriented flood flow channels to create the north-oriented Yampa River headwaters and the Egeria Park area Yampa-Colorado River drainage divide seen today. Large south-oriented floods leading to the Colorado River (while regional uplift was occurring) are inconsistent with accepted Cenozoic geologic and glacial history paradigm predictions, but are predicted by a newly proposed Cenozoic geologic and glacial history paradigm in which a thick continental ice sheet created a deep "hole" by eroding underlying bedrock and also by causing crustal warping that raised the present-day northern Colorado east-west continental divide as immense south-oriented meltwater floods flowed across it.
\end{abstract}




\section{Keywords}

Barbed Tributaries, Diverging and Converging Channel Complex, Egeria Park, Flat Tops Region, Geologic and Glacial History Paradigms, Park Range

\section{Introduction}

\subsection{Statement of the Research Question}

While rarely stated, the accepted Cenozoic geologic and glacial history paradigm (accepted paradigm) does not permit geomorphologists to explain most drainage divide origins. This paper illustrates how a recently proposed and fundamentally different Cenozoic geologic and glacial history paradigm (new paradigm) and detailed topographic maps available at the United States Geological Survey (USGS) National Map website permit the southern Routt County (Colorado) Yampa-Colorado River drainage divide origin to be determined. A Yampa River tributary (known as the Bear River) seen in Figure 1 and Figure 2 flows in a northeast direction before joining northwest-oriented Chimney Creek (which has south- and east-oriented tributaries) to become (north of Figure 2) the north-oriented Yampa River, which after flowing in north, northeast, and north directions, turns in a west direction to join the south-oriented Green River. South of Figure 1 the Green River joins the southwest-oriented Colorado River.

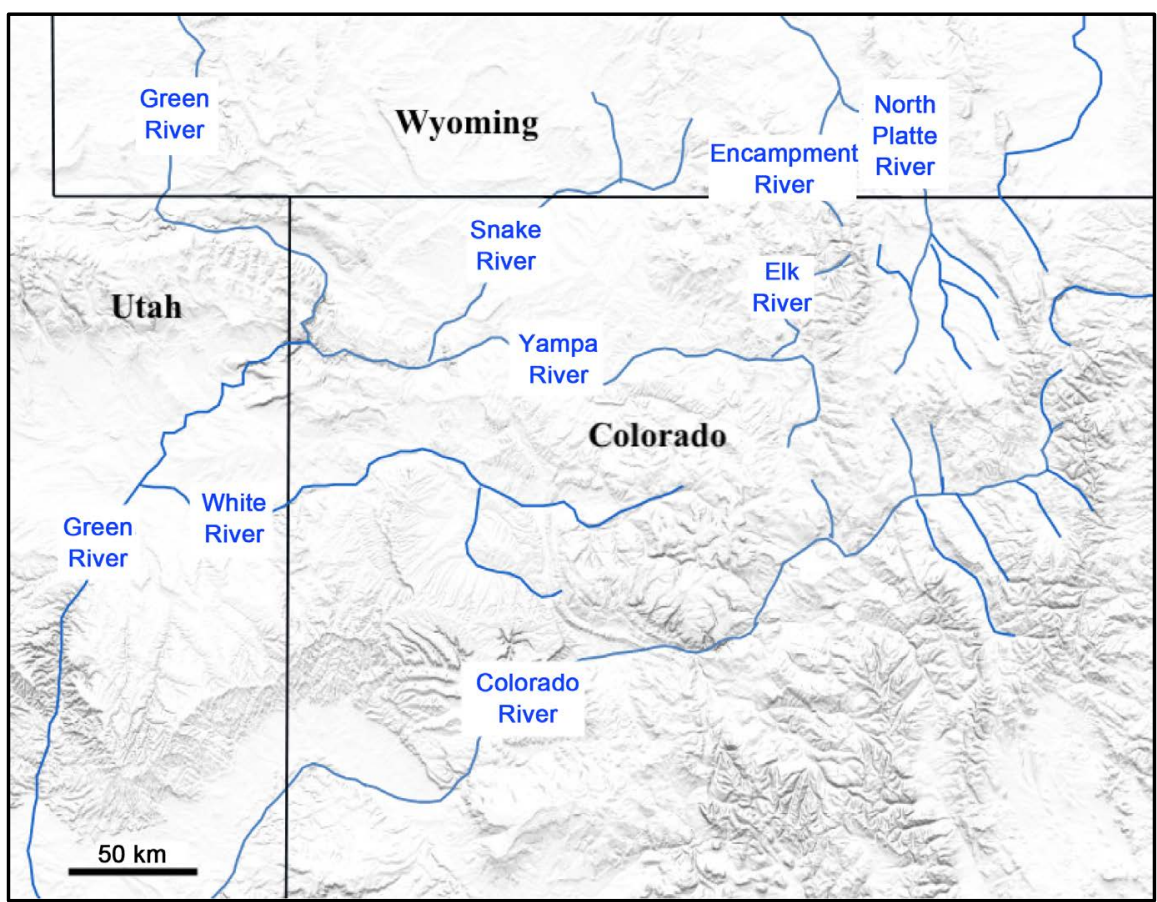

Figure 1. Modified map from the United States Geological Survey (USGS) National Map website showing the Yampa River location in northwest Colorado in relation to other rivers and the Utah and Wyoming State lines. 


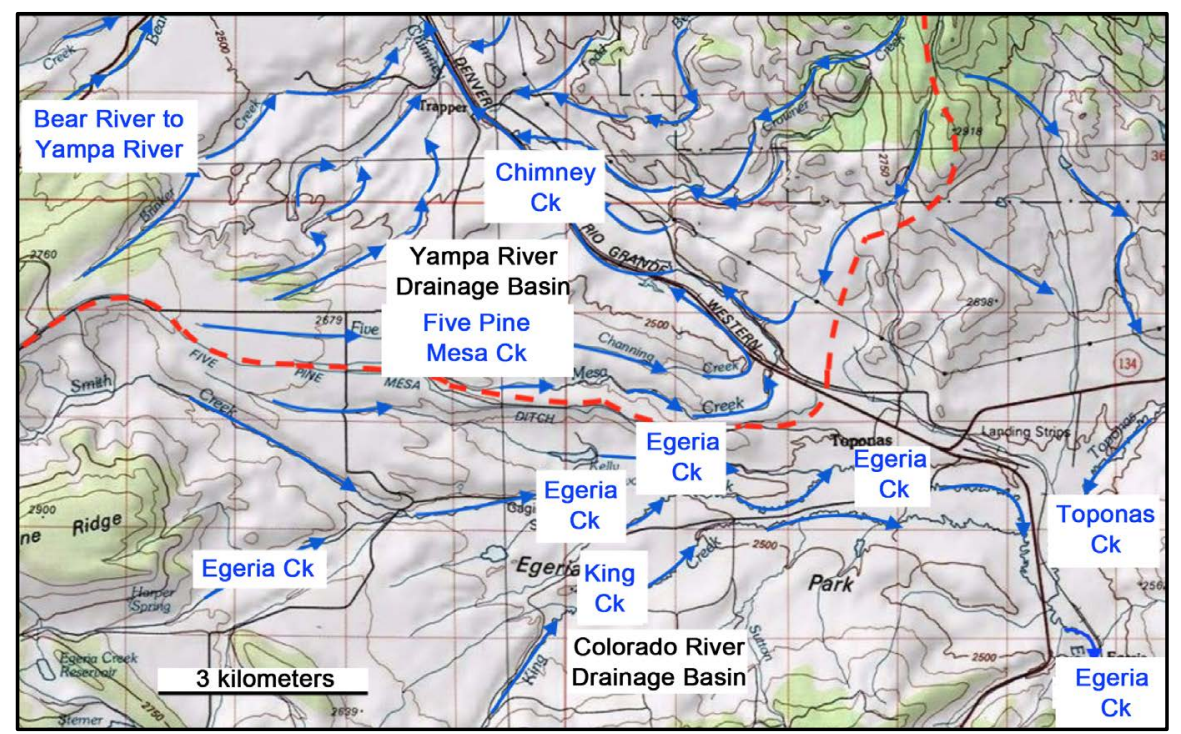

Figure 2. Modified topographic map from the USGS National Map website showing the Yampa-Colorado River drainage divide (dashed red line) in the Egeria Park area. Blue arrows emphasize drainage routes and flow directions. Contour interval is 50 meters.

Immediately to the south of where the north-oriented Yampa River begins is Egeria Park (seen in Figure 2) where a low drainage divide separates east- and southwest-oriented streams (which join northwest-oriented Chimney Creek to flow to the north-oriented Yampa River) from east-northeast and south-southeast oriented Egeria Creek (which flows to the Colorado River). Egeria Creek (as seen in Figure 3) has cut a narrow and deep canyon into the floor of a much wider 500-meter-deep valley (between King and Black Mountains) before joining Rock Creek which flows to the Colorado River as a barbed tributary (the Colorado River turns from flowing in a northwest direction to flow in west and then southwest direction near where Rock Creek joins it). An irrigation ditch known as the Five Pine Mesa Ditch (or Stillwater Ditch) moves water along the Yampa-Colorado River drainage divide from the Bear River headwaters and supplies irrigation water to fields located on both sides of the Yampa-Colorado River drainage divide.

At first, glance determining the Yampa River-Colorado River Egeria Park area drainage divide origin from topographic map evidence should be easy and should be important when trying to understand how the larger Colorado River drainage system developed, yet no published reports are known to mention ever trying to do so. Elevations at the low point where the highway and railroad cross the drainage divide (near Toponas) are about 2530 meters and Egeria Creek where it joins the Colorado River 20 kilometers (as a crow flies) to the south-southeast are 2020 meters while elevations in the Yampa River valley located 20 kilometers (as a crow flies) in the opposite direction are approximately 2280 meters, meaning the Yampa-Colorado River drainage divide is asymmetric with steeper slopes on the Colorado River side. High mountains, some of which are capped by Tertiary volcanic flows [1] [2] surround the Egeria Park region, which is located 


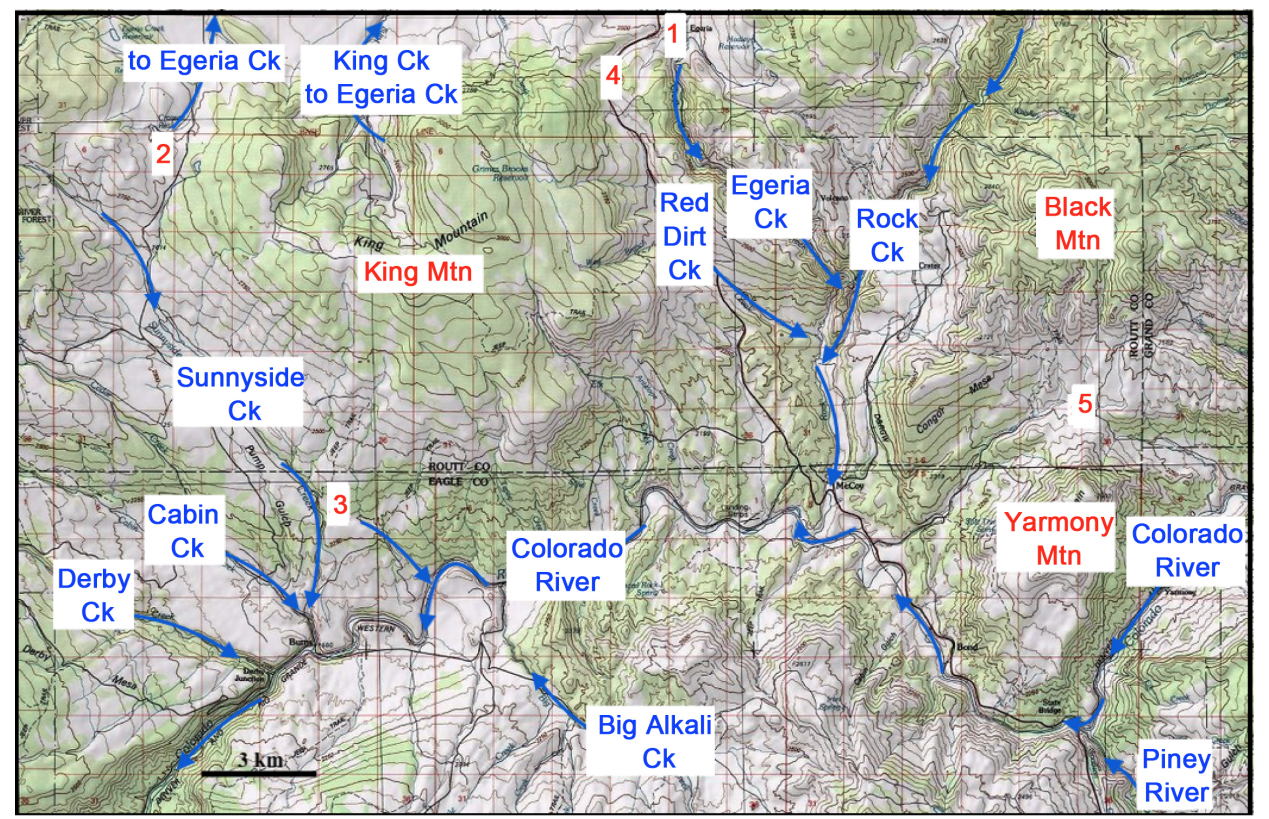

Figure 3. Modified topographic map from USGS National Map website showing drainage routes in the region to the south of Egeria Park. numbers identify locations discussed in the text. Contour interval is 50 meters.

between the Gore Range to the east and the high Flat Tops region (also known as the White River Plateau) to the west. Large amounts of water flowing in one direction or the other deeply eroded what is now the 500-meter-deep Egeria Park region which now links the north-oriented Yampa River valley with the south-southeast oriented Egeria Creek canyon, yet the accepted paradigm offers no large water source and must rely on explanations such as long periods of time, changed climatic conditions, and perhaps rapid melting of Park Range and Flat Tops region high elevation glaciers, none of which leads to the types of flow required to explain the Egeria Park region drainage development.

Only one geologist is known to have previously addressed the Egeria Park drainage divide origin. In an unpublished Ph.D. thesis, Kucera [[3]: pp. 404-405] suggests the southeast-oriented slope of Five Pine Mesa (on which the YampaColorado River drainage divide now crosses Egeria Park) as well as the southoriented slope of high surfaces on Green Ridge (extending north of Figure 2 northeast quadrant on which a north-to-south oriented Yampa-Colorado River drainage divide segment is located) indicate southeast-oriented drainage once flowed through Egeria Park. But, based on northeast-oriented terrace slopes to the north of Fine Pine Mesa Kucera argues "a northward flowing stream was able to extend its course headward thereby capturing the headwaters of an ancestral southeast-flowing Yampa River" and adds "This diversion is startling, for the water that formerly drained south, taking the most direct route to the Colorado River, now goes hundreds of miles [kilometers] farther north and west to meet the Green River." He further states "The capturing stream did not have structural or lithologic advantage over the ancestral Yampa River" and continues 
"the ancestral south-flowing Yampa was vulnerable to capture because its graded declivity, adjusted to the transportation of a coarse load, was steeper than the declivity of the north-flowing stream which transported mostly fine sands and silts." Kucera's capture explanation appears to defy common sense logic and adding to the problem he does not explain how the capturing north-flowing stream originated or where that stream went.

The lack of published literature discussing the Yampa River-Colorado River drainage divide origin is not unusual, in fact, geomorphologists since the mid-1900s have seldom asked and even more rarely answered drainage divide origin questions. Most drainage divides and other erosional landform features are frequently ignored anomalous evidence the accepted paradigm does not satisfactorily explain, which leads many geomorphologists to consider the determination of drainage divide and related erosional landform origins to be a nonproductive research activity. However, drainage divides and other erosional landforms exist and represent evidence needing explanations before the Cenozoic geologic and glacial history of a region can be properly understood. Kuhn [4] suggests failure to explain such anomalous evidence can lead to a new paradigm, which the author of this paper (Clausen) has used detailed topographic map evidence to develop [5]. The study reported here compares how the fundamentally different accepted and new paradigms explain southern Routt County, Colorado, Yampa-Colorado River drainage divide (and the north-oriented Yampa River headwaters drainage basin) detailed topographic map evidence, most of which previous investigators working from the accepted paradigm perspective have ignored or failed satisfactorily explain.

\subsection{Previous Work-Accepted Paradigm Interpretations}

Rocky Mountain drainage system origins including the Yampa River drainage system have long puzzled geomorphologists. Powell [6], who was an early geological explorer, proposed an antecedent origin for Green and Yampa River Unita Mountain canyons, although Emmons [[7]: pp. 194, 197] considered the Green and Yampa Rivers to have been superposed. Later White [8] provided more detailed evidence to support the Green and Yampa River antecedent origin, yet some years later Hancock [[9]: p. 188] argued "the Yampa River, instead of being antecedent, is superimposed and that the present course of the river was not established until after the emergence that followed the deposition of the Browns Park sediments." Ten years later Sears [[10]: p. 282] claimed "the theory of antecedence is absolutely untenable... it seems impossible that present courses of Green and Yampa rivers were established prior to the deposition... of the Browns Park Formation." This early debate (which was carried out without the benefit of detailed topographic maps available today) related to the Unita Mountain region where the west-oriented Yampa River joins the south-oriented Green River (see Figure 1) and did not mention the north-oriented Yampa River headwaters region further to the east. More recently Kucera [[3]: pp. 400-402] 
suggested superposition for most drainages in the north-oriented Yampa River headwaters region "including the course of the Colorado River".

More recent literature uses sediment and structural evidence in attempts to determine how the south-oriented Green River and its west-oriented Yampa River tributary routes evolved. For example, Hunt [[11]: p. 70] suggested "In Oligocene time, the ancestral headwaters of the Colorado River discharged westward to the Unita Basin across what is now the north-trending structural depression occupied by the headwaters of the Yampa River" and [[11]: p. 72] "The valleys of the Colorado... and the headward part of the Yampa are mostly 3000 - 4000 feet [914 - 1219 meters] deep and have eroded in the last 10 million years," but provides few details on how those valleys originated. Hansen [[12]: p. 54] includes diagrams showing Uinta Mountain region drainage development from late Oligocene to the present. He illustrates a high Unita Mountain range in late Oligocene time with an ancestral Green River turning east in Wyoming to flow across the Great Divide Basin. During the latest Oligocene to early Pleistocene time Hansen shows the Green River still flowing across the Great Divide Basin, but with subsidence and tilting enabling valleys eroding headward from the south to work their way toward the Wyoming Green River Basin and eastward along the west-oriented lower Yampa River valley. Finally, present-day drainage patterns are shown with the Green River now flowing across the Unita Mountains and the west-oriented Yampa River, but the maps do not extend far enough east to show the north-oriented Yampa River headwaters.

Most recently Aslan et al. [[13]: p. 50] in a field guide describing the northoriented Yampa River headwaters drainage area suggest "it is highly likely that the Brown's Park Formation and associated volcanic rocks represent a Miocene basin-fill sequence that predates the origin of the Yampa River." And based on Buffler [14], they suggest "This basin-fill would have extended across the presentday Yampa Valley, ...probably merging with Browns Park deposits in northwestern Colorado" and add "during the time of the Brown's Park Formation, sediment transport from the Upper Yampa Valley and Elkhead Mountains was northward into Wyoming. Under this scenario, streams originating in the Park Range [to the east of the north-oriented Yampa River valley and to the north of the Gore Range] flowed west toward the present-day Flat Tops, and then joined eastflowing rivers originating in the Uinta Mountains. Collectively this river system flowed north toward the ancestral Platte River in Wyoming" although details on how the Yampa River evolved from this ancestral Platte River drainage are not provided.

Several investigators have attempted to date the development of the western Colorado River drainage system, including its tributary Green and Yampa River drainage systems and have then used such dates to determine river valley incision rates. Much of this work relies on lava flows and other datable igneous rocks some of which are discussed in Larson et al. [15] who say the Colorado River system was initiated about $10 \mathrm{~m}$. y. ago following late Miocene (or perhaps 
early Pliocene) volcanic activity and sediment deposition when the region was subjected to uplift and other tectonism including reactivation of earlier Laramide structural features as well as creation of new warps, folds, and faults and as a result of [[15]: p. 156] "increased precipitation stemming from an increase in elevation and relief." Based on their study they state (p. 170) "unequivocal evidence for a Colorado River older than $10 \mathrm{~m}$. y. has yet to be produced." A similar study by Rosenberg et al. [16] added numerous additional data points which are used to suggest incision in the now north-oriented Yampa River valley adjacent to the Park Range during the past $10 \mathrm{Ma}$ to be in the 550- to 650-meter range with somewhat greater incision in the Flat Tops region. During the same time period they suggest 1200 to 1500 meters of incision occurred along the upper Colorado River system, although no reason for the difference is given, nor is the Yampa River drainage system development described.

Aslan et al. [[17]: Figure 14, p. 134] attempted to reconstruct late Eocene to early Oligocene (ca 36-27 Ma) river systems in the Utah Uinta Mountain and Wyoming Green River Basin regions. Their map which is based on sedimentologic and paleo-valley data shows eight south-oriented and four north-oriented drainages flowing from the east-west oriented Uinta Mountain crest and one south-oriented drainage from the Wyoming Rock Springs uplift area. The Yampa River apparently did not exist but the map shows a speculative southeastoriented river system with headwaters in the Wyoming Fold and Thrust Belt and possibly the Wind River Mountains and which may have dipped into northwest Colorado before turning in a north direction to enter Wyoming's Great Divide Basin in addition to a speculative west-flowing river system across the same southwest Wyoming region. Their speculative mainstem rivers north of the Uinta Mountains [[17]: p. 115] could have had headwaters "located east of the Unita Mountains, or in the Challis and Absaroka volcanic fields and the Wind River Mountains located to the northwest of the region. The question of whether... the Bishop Conglomerate represents part of integrated river system that was a precursor to the Platte River remains unresolved."

Interestingly all of the above cited accepted paradigm literature describes regional drainage development in vague and very general terms and leaves to the reader's imagination most details on how the present-day drainage systems evolved. This lack of specificity is remarkable because geologists have been trying to decipher the regional drainage history for almost 150 years and while amassing large quantities of regional igneous, sedimentologic, and structural data the fundamental regional drainage history questions first asked almost 150 years ago still remain unresolved and also because excellent detailed regional topographic maps have been available in hard copy format for more than 60 years and in digital format for about 20 years and can now be easily accessed at the United States Geological Survey (USGS) National Map website. These maps provide much of the information required to reconstruct in great detail how drainage routes seen today evolved from earlier drainage routes. Yet no cited re- 
searchers reported using topographic map interpretation techniques to reconstruct how modern-day regional drainage routes evolved, perhaps because the accepted paradigm does not permit detailed topographic map drainage system evidence to be interpreted in a meaningful way.

\subsection{Previous Work-New Paradigm Interpretations}

The author of this paper (Clausen) has developed a new paradigm to explain Missouri River drainage basin detailed topographic map drainage system evidence [5] and to date more than two dozen demonstration papers have been published to illustrate how the new paradigm interprets detailed topographic map evidence in diverse and specific Missouri River drainage basin regions. These regions include the North Platte River headwaters area directly to the east of the northoriented Yampa River headwaters [18] and the Wyoming Great Divide Basin region located to the north of the Yampa River [19]. In addition, another demonstration paper [20] interprets topographic map evidence along the Wind River-Sweetwater River drainage divide located directly to the north of the Wyoming Great Divide Basin. In each of the three mentioned demonstration papers detailed topographic map evidence is interpreted to show how massive southoriented floods initially flowed across what is now the North American east-west continental divide moving from the present-day Missouri River drainage basin (now draining to the Gulf of Mexico) to the Colorado River drainage basin (now draining to the Pacific Ocean) and were then subsequently blocked by mountain uplift and forced to flow in other directions.

The first mentioned demonstration paper [18] identifies four mountain passes crossing what is today the east-west continental divide in the northern Park Range where large volumes of south-oriented water flowed from the now north-oriented North Platte River drainage basin into the Yampa River drainage basin. The first of these mountain passes is not named on detailed topographic maps, but is 450 to 550 meters deep and links now north-oriented Encampment River headwaters (flowing to the north-oriented North Platte River) with the west-oriented North Fork Elk River (flowing to the Elk and Yampa Rivers, see Figure 1). Somewhat shallower Red Dirt and Ute Passes are interpreted to have been eroded as Park Range uplift was occurring when a south-oriented flood flow channel diverged and then converged with south-oriented flow on the North Platte River alignment, but which was captured by headward erosion of the west-oriented Middle Fork Elk River valley. Further to the south along the Park Range crest ridge (which is also the east-west continental divide) is Buffalo Pass which links what is now a northeast-oriented tributary flowing to the North Platte River with southwestoriented Fish Creek which now joins the north-oriented Yampa River as a barbed tributary. These mountain passes are interpreted to be erosional features carved by large south-oriented floods moving water toward what are now the north-oriented Yampa River tributary valleys and/or directly to what is now the north-oriented Yampa River valley. 
While as already described accepted paradigm investigators refer in vague and general terms to an ancestral North Platte River drainage system, several new paradigm demonstration papers outline in great detail how detailed topographic map evidence shows how North Platte River drainage system development can be reconstructed. These papers describe how North Platte River valley and South Platte River valley headward erosion captured in sequence immense floods in what are now high elevation Colorado mountain areas [21] and in lower elevation western Nebraska Great Plains regions [22]. In addition, another demonstration paper [23] illustrates how headward erosion of the southeast-oriented North Platte River valley beheaded and reversed massive south-oriented floods that had been flowing across a rising northern Laramie Mountain Range and beheaded and reversed south-oriented flood flow on what is now the north-oriented North Platte River (flowing from northern Colorado to central Wyoming). Cited and uncited demonstration papers illustrate the new paradigm's remarkable ability to explain the detailed topographic drainage system and erosional landform evidence.

How does the new paradigm (which leads to a fundamentally different Cenozoic geologic and glacial history than the accepted paradigm) explain the immense south-oriented floods that first flowed across what is now Wyoming and northern Colorado east-west continental divide and which were then forced by mountain uplift to flow in other directions? Unlike in accepted paradigm interpretations the new paradigm describes a continental ice sheet formed deep "hole" created by deep ice sheet erosion and by crustal warping that raised surrounding mountain ranges and plateau areas. The deep "hole" southwest rim is today the Montana, Wyoming, and northern Colorado east-west continental divide although the rim was gradually raised as massive south-oriented meltwater floods flowed across it and as the deep "hole" rim rose the floods were forced to flow along it and finally blocked and forced to flow in north directions toward the thick continental ice sheet margin, which was located where accepted paradigm researchers usually consider continental ice sheet margins to have been. Late during the thick ice sheet's melt history large meltwater floods were diverted into deep "hole" space being opened up by ice sheet melting and flowed first across the ice sheet floor to southern outlets and the Gulf of Mexico, but later flowed along shorter routes across the decaying ice sheet floor to reach the North Atlantic and Arctic Oceans. This diversion of meltwater floods from south to north changed the climate, which caused north-oriented meltwater and other north-oriented drainage to freeze around decaying thick ice sheet remnants and to form a new and much thinner ice sheet and which also enabled glaciers to develop in what were then "newly" uplifted mountain range areas.

\section{Research Method}

The study reported here interpreted detailed topographic maps available at the United States Geological Survey (USGS) National Map website. Maps covering 
the entire north-oriented Yampa River drainage basin and nearby areas were investigated to note evidence of divide crossings (low points along surrounding and internal drainage divides), through valleys crossing drainage divides (deeper and more prominent divide crossings), barbed tributaries, and unusual drainage route direction changes. Low points along drainage divides (unless there was reason to believe otherwise) were interpreted to be where water flowing in one direction or the other had once crossed the drainage divide and maps were searched to determine the former flow direction and why former drainage routes no longer exist. Multiple closely spaced low points along drainage divides were interpreted to be possible evidence of flood formed anastomosing channel complexes that once crossed the region. This interpretation was supported by evidence of abandoned through valleys connecting present-day drainage route valleys which were also interpreted to be evidence of diverging and converging flood flow channels.

Barbed tributaries were interpreted to be possible stream capture and/or drainage reversal evidence. Multiple barbed tributaries flowing to the same trunk stream were interpreted to be possible evidence the trunk stream valley eroded headward across a large flood formed anastomosing channel complex. Likewise, abrupt drainage route direction changes were considered to be probable stream capture evidence, which may have included a flow direction reversal. Divide crossing floor elevations were obtained and compared where appropriate to determine channel erosion depths and channel abandonment sequences. In each case, map evidence was studied to develop if possible multiple hypotheses from each of the two competing paradigm perspectives as to how the probable capture and drainage reversal events might have occurred. The goal was to apply the method of multiple working hypotheses as T. C. Chamberlin [24] originally proposed it and to determine using common sense logic which of the two paradigms was able to develop the best hypotheses with the ability to explain the observed topographic map evidence.

\section{Results}

\subsection{Egeria Park and Area to the South Drainage System Evidence}

The Yampa River-Colorado River drainage divide in Egeria Park (seen in Figure 2 ) is located on east-southeast sloping Five Pine Mesa which is drained by eastsoutheast oriented Five Pine Mesa Creek, which makes an abrupt turn to join northwest-oriented Chimney Creek (which flows to the north-oriented Yampa River). Immediately to the south of Five Pine Mesa Creek and in slightly deeper channels are east-southeast oriented Egeria Creek tributaries, which flow to eastnortheast oriented Egeria Creek, which also abruptly turns in Figure 2 southeast corner to flow in a south-southeast direction to join Rock Creek and then the Colorado River (seen in Figure 3). Complicating the drainage history interpretation northwest-oriented Chimney Creek has south-oriented tributaries while east-northeast and south-southeast oriented Egeria Creek has north-oriented tri- 
butaries (seen in Figure 3). These barbed tributaries document a drainage history which according to Kucera [3] ended with headward erosion of a northoriented valley that beheaded and partially reversed what had previously been a south-oriented drainage system. Such an interpretation is consistent with most Figure 2 drainage routes although the interpretation does not explain northoriented Egeria Creek tributaries such as King Creek (which originates on King Mountain-see Figure 4).

Location 1 in Figure 3 is where Egeria Creek enters south- and southeastoriented Egeria Canyon which leads to south-oriented Rock Creek and the Colorado River. Note how the Colorado River flows in a southwest direction before joining northwest-oriented Piney River and then turns in a northwest direction to join south-oriented Rock Creek before turning in a west and southwest direction. Also note how several Colorado River tributaries from the north including Egeria, Red Dirt, Sunnyside, Cabin and Derby Creeks flow in southeast directions and how at least some tributaries from the south including the Piney River and Big Alkali Creek flow in northwest directions as does the Colorado River between its confluence with the Piney River and with Rock Creek. As previously mentioned, elevations at the lowest point along the Yampa River-Colorado River drainage divide in Egeria Park are about 2530 meters yet at location 2 (west of King Mountain) a 200-meter-deep low point with a floor elevation of about 2790 meters links a north-oriented Egeria Creek tributary with south-oriented drainage to Sunnyside Creek. Water flowing between present-day Egeria Creek and the Colorado River eroded that location 2 notch yet at the same time water must have also been eroding the much deeper Egeria Creek valley located to the east of the detailed King Mountain topographic map seen in Figure 4. It is difficult

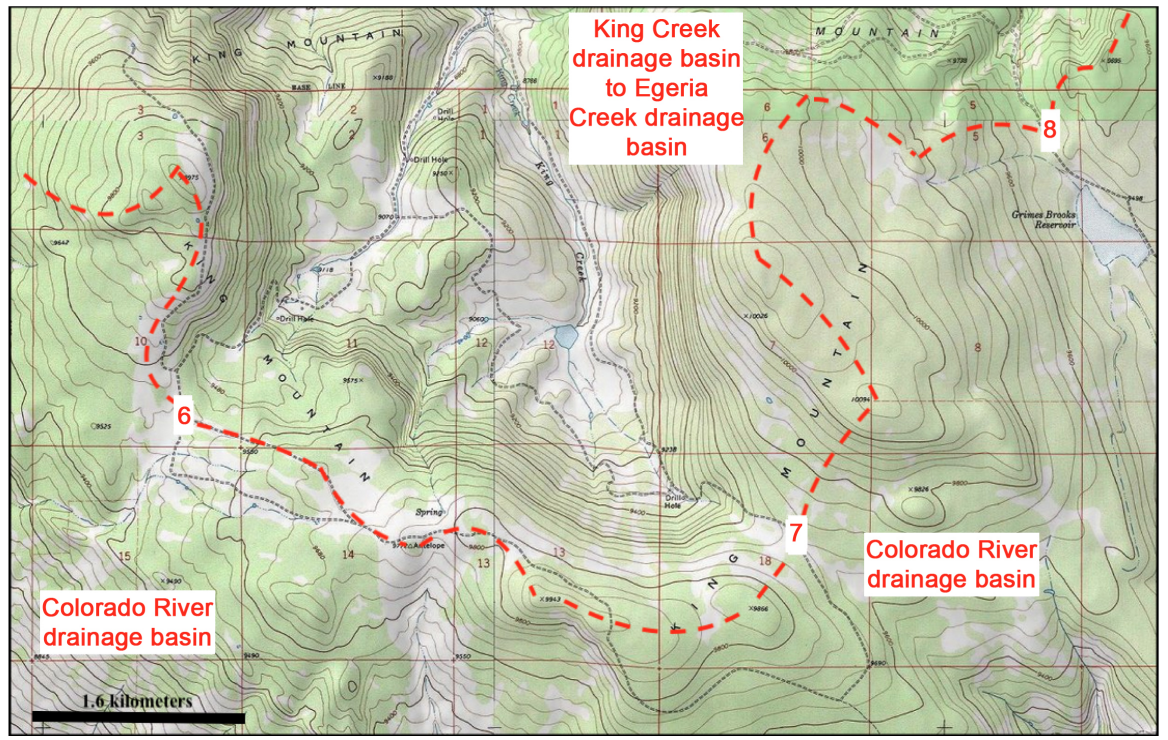

Figure 4. Modified detailed topographic map from the USGS National Map website showing Egeria Creek-Colorado River drainage divide (red dashed line) along the King Mountain crest. Numbers refer to divide crossings discussed in the text. Contour interval is 40 feet (12 meters). 
to explain the low point at location 2 unless water diverged from Egeria Creek to flow across location 2 so as to reach Sunnyside Creek.

Location 3 (in Figure 3) is where headward erosion of a south-oriented Cabin Creek tributary captured Sunnyside Creek, but less obvious are reasons why Sunnyside, Cabin, and Derby Creeks (and many other streams further to the southwest) flow in southeast directions to join the southwest-oriented Colorado River. Just as significant a well-defined through valley at location 4 (through which a highway has been built) links the south-southeast oriented Red Dirt Creek valley with the Egeria Creek valley. Also, to the east of the Egeria Creek Canyon is another unmarked (in Figure 3) through valley leading from location 1 to Rock Creek. Like with the Red Dirt Creek valley, the unmarked through valley is evidence water not only diverged from the Egeria Creek valley to flow into the Red Dirt Creek valley but also diverged to flow in the unmarked valley, suggesting large and prolonged south-oriented diverging and converging flood flow channels. It is difficult to explain these three diverging and converging valleys unless extremely large volumes of water once flowed across and then from Egeria Park.

Figure 4 provides a modified detailed topographic map of the King Mountain area between locations 1 and 2 (in Figure 3) on which locations 6, 7, and 8 identify additional divide crossings where water once flowed across the Egeria CreekColorado River drainage divide. Elevations at location 6 and 8 divide crossings are approximately 2900 meters and at the location 7 divide crossing are approximately 2950 meters and are significantly higher than the elevation of the divide crossing at location 2 (in Figure 3) which is significantly higher than the lowest Egeria Park Yampa River-Egeria Creek divide crossing seen in Figure 2. These divide crossings can be explained if the east-northeast oriented Egeria Creek valley eroded headward in a west direction excavating the Egeria Park region and beheading and reversing flow in what must have been a large south-oriented complex of diverging and converging channels to create what are now north-oriented Egeria Creek tributaries (glacial ice may have subsequently contributed to the erosion of the north-oriented King Creek headwaters area to create the north-facing basin seen in Figure 4), although the south-oriented channels must have initially flowed on a surface equivalent to the King Mountain crest ridge (which today has elevations exceeding 3000 meters). Such an interpretation implies large south-oriented floods probably lowered deeper Egeria Park areas by almost 500 meters.

\subsection{Yampa Valley and Adjacent Area Evidence to the North of Egeria Park}

To the north of Egeria Park (and Figure 2) the Yampa River is formed at the confluence of northeast-oriented Bear River and northwest-oriented Chimney Creek and then flows in a north-northwest oriented valley to enter Figure 5 where it turns in a northeast direction before turning to flow directly north along the Park Range western flank (the map in Figure 5 shows the Yampa River valley 


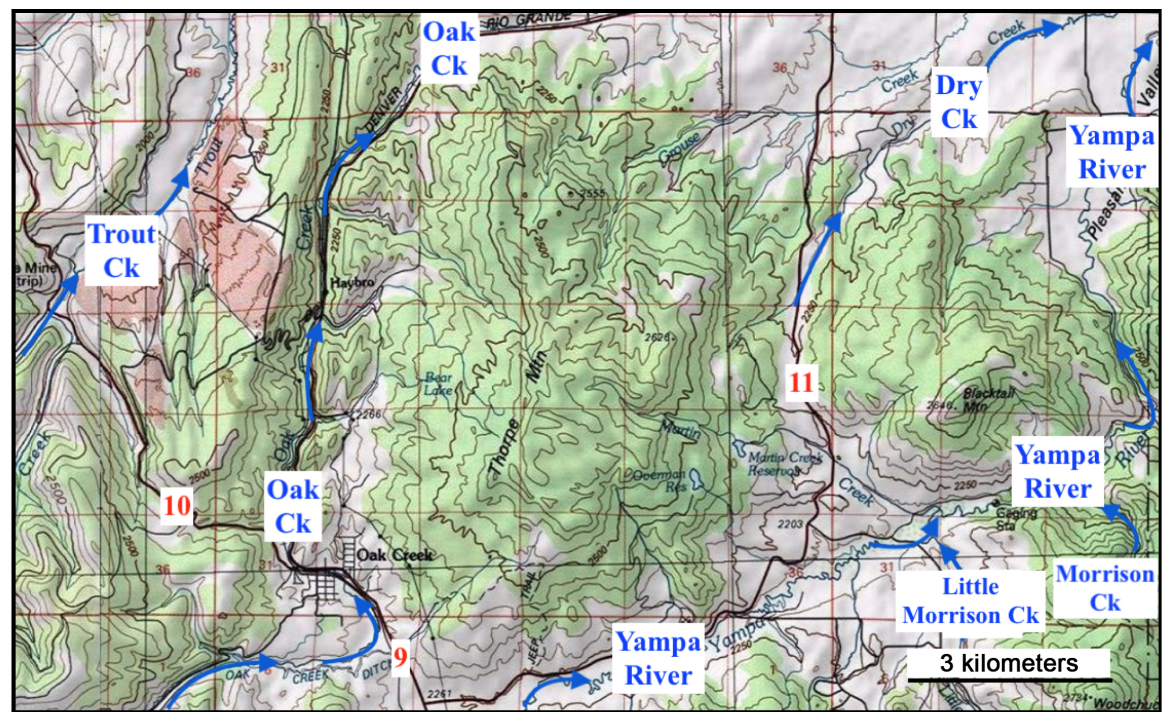

Figure 5. Modified topographic map from USGS National Map website showing through valleys and divide crossings (identified by red numbers) linking the north-, northeast-, and north-oriented Yampa River valley with north- and northeast-oriented Yampa River tributary valleys. Contour interval is 50 meters.

before the construction of dams now flooding some valley areas). Quite obvious in Figure 5 are divide crossings at locations 9, 10, and 11 which help define what must have been a large complex of diverging and converging channels. The divide crossing at location 9 links the Oak Creek and Yampa River valleys. Today Oak Creek flows in a northeast direction to reach Figure 5 and after leaving the figure area flows in a northeast direction to join the north-oriented Yampa River. The divide crossing at location 10 links the Trout Creek and Oak Creek valleys. Trout Creek flows in a northeast direction to reach Figure 5 and after leaving the figure continues in a north direction to reach the west-oriented Yampa River (downstream from where the Yampa River turns to flow in a west direction). The divide crossing at location 11 is Yellow Jacket Pass which links northeast-oriented Dry Creek (flowing to the north-oriented Yampa River) with southeast-oriented Martin Creek (flowing to the northeast-oriented Yampa River segment). The divide crossings at locations 9,10 , and 11 help to identify a large floodformed diverging and converging valley complex.

Lynx Pass (a divide crossing not seen in this paper's figures) links the northwest-oriented Morrison Creek valley (seen joining the Yampa River in Figure 5) with the south-southeast oriented Rock Creek valley (seen joining Egeria Creek, Red Dirt Creek, and an unnamed valley in Figure 3). Northwest- and north-oriented Little Morrison Creek begins on the floor of the Morrison Creek valley and adjacent to Morrison Creek. Then as the Little Morrison and Morrison Creek valleys diverge, they are separated by Woodchuck Hill, which stands more than 300 meters above the unseen and deep valley where the Morrison and Little Morrison Creek valleys diverge. The roughly parallel Little Morrison and Morrison Creek valleys form another diverging and converging valley example as do the 
much longer Morrison Creek-Lynx Pass-Rock Creek and the Yampa River-Chimney Creek-Egeria Creek valleys. The large diverging and converging valley complex defined by divide crossings at Lynx Pass, the Little Morrison Creek headwaters valley, and at locations 9,10 , and 11 suggest regional erosion by a large flood formed anastomosing channel complex. While the direction of flood flow is not immediately obvious barbed tributaries seen in Figure 6 suggest the flow was in a south direction. If so, events such as regional uplift and/or beheading and capture by headward erosion of a much deeper valley (to the north of Figure 5) have since reversed the drainage direction.

Information regarding the original flow direction in what is now the northoriented Yampa River valley segment is seen in Figure 6 where the north-oriented Yampa River turns in a west direction. Numerous south- and southwest-oriented tributaries flow to the Yampa River north-oriented valley segment's northern end and provide excellent evidence south-oriented drainage preceded the present-day north-oriented Yampa River. Not seen in Figure 6 is north-oriented Trout Creek, which is located west of the figure and which joins the west-oriented Yampa River near to where the south-oriented Elk River joins the Yampa River. As previously mentioned, a new paradigm demonstration paper [18] describes how mountain passes across the east-west continental divide link Elk River tributaries with the north-oriented Encampment River, which flows to the north-oriented North Platte River and how Buffalo Pass across the east-west continental divide links southwest-oriented Fish Creek with a northeast-oriented North Platte River tributary. The Elk River and Fish Creek linkages and similar, but somewhat less obvious linkages suggest a large complex of diverging and converging streams of southoriented water once flowed from what is today the north-oriented North Platte

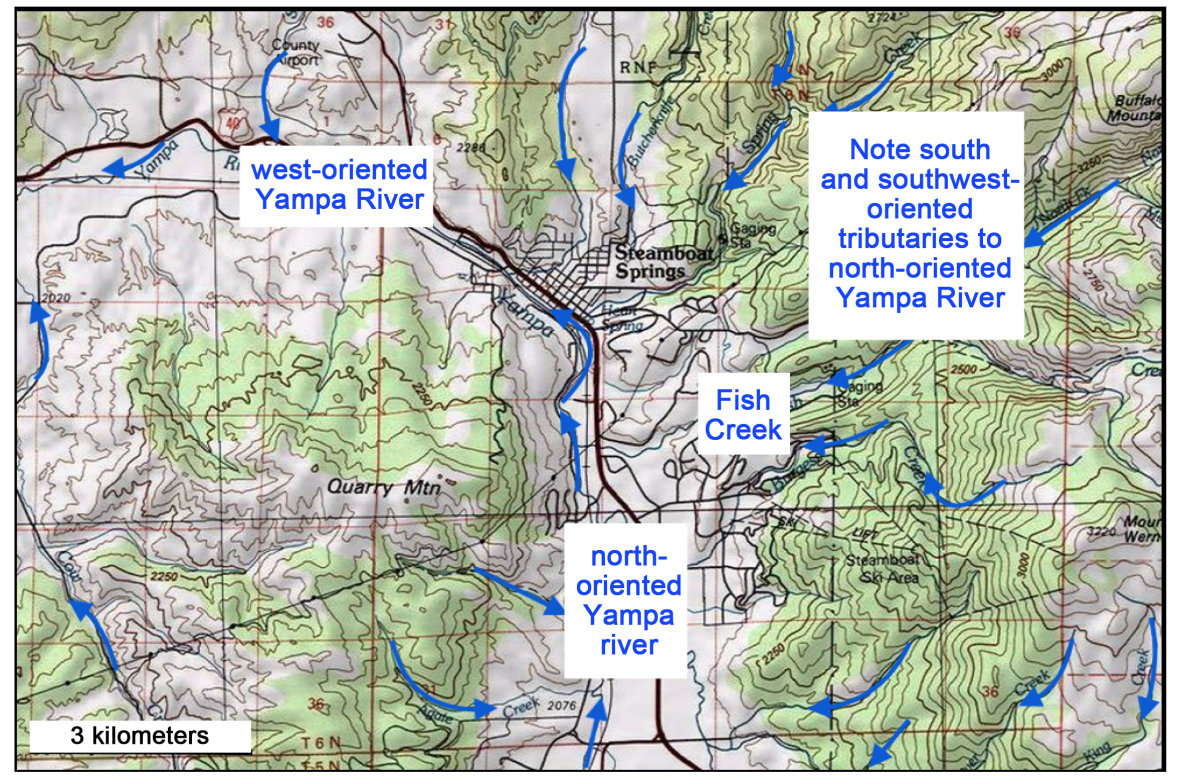

Figure 6. Modified map from USGS National Map website showing where the Yampa River turns in a west direction and barbed (south-oriented) tributaries flowing to the northoriented Yampa River valley segment. Contour interval is 50 meters. 
River valley to reach what is today the north-oriented Yampa River valley. Large and prolonged floods of south-oriented water are consistent with the southoriented barbed tributaries flowing to the Yampa River in Figure 6 and diverging and converging valley complexes described by Figures 3-5 map evidence and with the Egeria Park evidence suggesting a Yampa River flow reversal occurred.

Perhaps the most interesting previously unanswered Yampa River related question is why after flowing in a north direction does the Yampa River turn to flow in a west direction as seen in Figure 1 and Figure 6. Obviously a capture has occurred. Previous investigators without providing any details and working from the accepted paradigm perspective imply the north-oriented Yampa River headwaters may have originated as part of an ancestral north-oriented North Platte River drainage system. If so, headward erosion of the west-oriented Yampa River valley captured north-oriented Yampa River headwaters. However, to explain the previously described (in the north-oriented Yampa valley) diverging and converging valleys and barbed tributaries such an explanation requires large northoriented floods coming from what is now the deep Colorado River valley, which may be why previous investigators fail to provide any details. An alternate explanation consistent with the barbed tributary evidence and with new paradigm predictions is large and prolonged south-oriented floods eroded what is now the north-oriented Yampa River headwaters valley (and diverging and converging valley complex) and were captured by headward erosion of a much deeper westoriented Yampa River valley, which combined with ongoing regional uplift triggered the reversal of flow that created what are today the north-oriented Yampa River headwaters. If so, the regional uplift must have been occurring as large south-oriented floods were flowing across the region.

\subsection{Northeast-Oriented Bear River Valley and Egeria Creek Headwaters Areas}

One complication to the south-oriented flood flow interpretation is the northeast-oriented Bear River which flows in a large valley from the high elevation Flat Tops region to join the north-to-south oriented diverging and converging valley complex. Kucera [[3]: p. 404] suggests the Yampa River headwaters (his name for the northeast-oriented Bear River) before being captured by a northoriented stream turned in an east direction to flow into Egeria Park and then to the Colorado River. While consistent with a south-oriented flood interpretation Kucera's explanation does not explain how the large northeast-oriented Bear River valley (which was subsequently glaciated) had been eroded. A valley glacier may have widened and deepened the valley although a northeast-oriented water-eroded valley must have existed prior to the valley glacier's formation.

Detailed topographic maps suggest large southeast-oriented floods probably eroded the northeast-oriented Bear River headwaters valley which would only be possible if floodwaters once flowed across the high Flat Tops region. Locations 12 and 13 in Figure 7 identify divide crossings linking southeast- and then north- 
east-oriented Egeria Creek headwaters with short north-oriented tributaries flowing to the northeast-oriented Bear River and location 14 identifies a divide crossing between the Egeria Creek headwaters valley and the southeast-oriented Sunnyside Creek headwaters valley. South- and/or southeast-oriented water flowing from what is today the deep northeast-oriented Bear River valley eroded each of these divide crossings with the water flowing first to the southeast-oriented Sunnyside Creek headwaters valley before being captured by Egeria Creek valley headward erosion and subsequently being captured by northeast-oriented Bear River valley headward erosion (to the north of Figure 7). Not seen is a well-defined divide crossing linking the southeast-oriented Sunnyside and Cabin Creek headwaters valleys. Further west a divide crossing links the southeast-oriented North Fork Derby Creek headwaters valley with the northeast-oriented Bear River headwaters valley. Shallower and even higher elevation divide crossings located on the Flat Tops upland surface link the southeast-oriented Middle Fork Derby Creek headwaters valley with northwest-oriented Fraser Creek and the North Fork White River headwaters valleys. These and similar divide crossings and linkages suggest the east-northeast oriented Egeria Creek and northeast-oriented Bear River headwaters valleys probably eroded headward across a large southeast-oriented flood-formed diverging and converging channel complex that moved water across what is now the high elevation Flat Tops region.

Apparently as large south-oriented floods eroded the region between the presentday Flat Tops and Park Range (where the Yampa River diverging and converging valley complex is now located) the Egeria Creek and Bear River headwaters valleys eroded headward from that deeper south-oriented diverging and converging channel complex to capture southeast-oriented floodwaters still moving

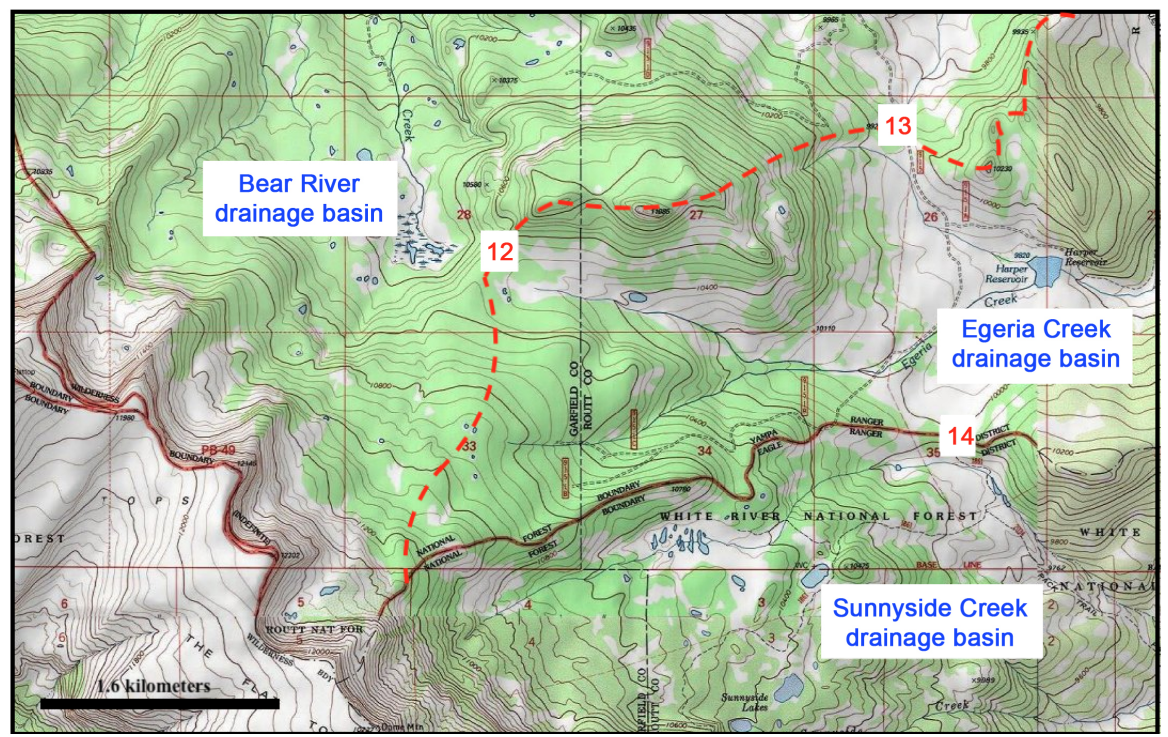

Figure 7. Modified topographic map from USGS National Map website showing Egeria Creek headwaters relationship to Sunnyside Creek headwaters and to north-oriented Bear River tributaries. Red dashed line shows Bear River-Egeria Creek drainage divide. Numbers identify locations discussed in the text. Contour interval is 50 feet (15 meters). 
across what is now the Flat Tops region. The Egeria Park basin was apparently eroded as floodwaters that had moved in a south direction in diverging and converging channels along what is now the north-oriented Yampa River valley were joined by southeast-oriented floodwaters that had flowed across what is now the Flat Tops region and then had then been captured and diverted through the Egeria Park basin by headward erosion of the east-northeast Egeria Creek valley and later by northeast-oriented Bear River valley headward erosion. Prior to headward erosion of the deep east-northeast oriented Egeria Creek headwaters valley elevations in the Egeria Park area must have been high enough that south-oriented flood flow could move across King Mountain as seen in Figure 4. Headward erosion of the deep Egeria Creek valley beheaded and reversed those high-level south-oriented flood flow channels so as to create the north-oriented Egeria Creek tributaries seen in Figure 3 and Figure 4.

The concept of southeast-oriented flood flow across the Fat Tops (or White River Plateau) region raises questions about the Colorado River valley origin. While not studied in detail Figure 3 illustrates a northwest-oriented segment of what is primarily a southwest-oriented river and shows multiple southeast- and northwest-oriented Colorado River tributaries. Further, location 5 (in Figure 3) identifies a divide crossing between Black and Yarmony Mountains that links what are today southwest- and southeast-oriented Colorado River tributaries. The through valley defined by this divide crossing is deep enough that it is tempting to suggest the Colorado River once flowed along that route, although common sense logic dictates that if Colorado River flowed along that route the Colorado River probably was also flowing along what is now the more southerly Colorado River southwest- and northwest-oriented route as well (in other words the water would have been flowing in diverging and converging channels). If so, regional and mountain uplift must have been occurring and the southern route (the present-day Colorado River route) was able to erode its valley deeper than the northern route. Such a situation would have led to the northern route's abandonment and the elevation of location 5 above the Colorado River valley floor suggests more than 300 meters of mountain range uplift has occurred since that northern route was abandoned.

\section{Discussion}

Evidence for a previous south-oriented drainage system that must have moved large quantities of water through a large complex of diverging and converging channels across what is now the north-oriented Yampa River headwaters region is obvious on detailed topographic maps (e.g. Figures 3-6) yet previous investigators who worked from the accepted paradigm perspective have not reported such evidence. The accepted paradigm uses drainage systems similar to those seen today operating over long periods of time to explain most erosion events and several cited accepted paradigm investigations calculated regional river valley incision rates. Those incision rate studies did not determine how present-day 
drainage systems developed although the calculated incision rates imply today's rivers have been deepening their valleys over long time periods at relatively constant rates. If large south-oriented floods flowed into and across the region (as the new paradigm and the topographic map evidence strongly suggests) a different regional valley deepening picture emerges. Topographic map evidence suggests the east-northeast oriented Egeria Creek and northeast-oriented Bear River headwaters valleys eroded headward across massive southeast-oriented floods and it is possible the southwest-oriented Colorado River valley segment seen in Figure 3 previously eroded headward across the same massive southeast-oriented floods and in doing so beheaded and reversed flow on a major southeast-oriented flood flow channel so as to create the northwest-oriented Colorado River segment seen in Figure 3. If so, previously determined long term river valley incision rates are probably meaningless.

This paper has pointed out many differences between accepted and new paradigm interpretations of the Yampa River headwaters region drainage history. Some differences arise because previous workers focused on the interpretation of sediment and igneous rock data while neglecting erosional landform evidence (often best observed on detailed topographic maps). In contrast the study reported here only used topographic map evidence and has not tried to explain how middle and late Cenozoic sedimentary rocks were deposited. Other differences between the two paradigm interpretations arise because the two paradigms describe incommensurable Cenozoic geologic and glacial histories, which cannot be easily compared. With that said, the prolonged new paradigm south-oriented meltwater floods would have not only eroded the Yampa River headwaters regions as described here, but probably transported and deposited what previous investigators have described as Oligocene, Miocene, and Pliocene sediments. Conglomerates and other coarse-grained alluvium in some of those sediments can probably be reinterpreted as flood transported and deposited materials, although flow directions determined in some previous investigations do not always agree with flood flow directions reported here. Much additional work needs to be done so the regional sediment data and detailed topographic map evidence do not describe different and incompatible geologic histories.

\section{Conclusions}

Detailed topographic maps provide an excellent information source available to researchers wanting to answer drainage history questions, however, answers obtained often differ from accepted Cenozoic geologic and glacial history paradigm expectations. In the study reported here, the topographic maps show southoriented (barbed) tributaries flowing to what is now the north-oriented Yampa River headwaters valley indicate south-oriented water once flowed into and then across the region. Divide crossings (low points along drainage divides) link adjacent valleys and indicate the south-oriented water flowed in a large complex of diverging and converging channels, such as might be expected to form during massive south-oriented floods and those northeast-oriented valleys eroded head- 
ward from deeper southeast-oriented flood flow channels to capture what were probably higher elevation southeast-oriented floodwaters. Headward erosion of what is now the west-oriented Yampa River valley probably beheaded and reversed south-oriented flood flow so as (with the help of regional uplift) to create what are now the north-oriented Yampa River headwaters and the Egeria Park area Yampa River-Colorado River drainage divide. In other words, detailed topographic map evidence can be used to reconstruct how present-day north- oriented Yampa River drainage basin drainage routes evolved during massive south- and southeast-oriented floods.

The accepted Cenozoic geologic and glacial history paradigm does not predict large south-oriented floods flowed across the north-oriented Yampa River headwaters drainage basin and previous investigators have not described or explained the detailed topographic map evidence. From the accepted paradigm perspective, the large south-oriented floods across the Yampa River headwaters region did not happen and the detailed topographic map evidence is unexplainable and must be ignored. However, a new and fundamentally different Cenozoic geologic and glacial history paradigm [5] predicts massive south-oriented floods should have flowed across what is today the north-oriented Yampa River headwaters drainage basin, which is what the detailed topographic map evidence shows. Much work remains to be done both to interpret surrounding region topographic map evidence and also to restudy regional middle and late Cenozoic sediments to determine if those sediments might be flood deposits. However, the study reported here supports the new paradigm prediction that immense south-oriented continental ice sheet meltwater floods flowed to and entered the Colorado River valley.

\section{Acknowledgements}

New paradigm development began while the author was employed as a Minot State University faculty member where other faculty members, students, and library staff greatly assisted in providing access to needed hard copy topographic maps. Arthur Strahler, then at Columbia University, and Brainerd Mears, Jr., then at the University of Wyoming during the 1960s introduced the author to numerous unsolved drainage history problems.

\section{Conflicts of Interest}

The author declares no conflicts of interest regarding the publication of this paper.

\section{References}

[1] Madole, R.F. (1989) Surficial Geologic Map of the Meeker 30' X 60' Quadrangle, Garfield, Moffat, Rio Blanco, and Routt Counties, Colorado. United States Geological Survey Miscellaneous Investigations Series Map I-1823, Scale 1:100,000.

[2] Madole, R.F. (1991) Surficial Geologic Map of the Steamboat Springs 30’ X 60' Qu- 
adrangle, Grand, Jackson, and Routt Counties, Colorado. United States Geological Survey Miscellaneous Investigations Map I-1825, Scale 1:100,000.

[3] Kucera, R.E. (1962) Geology of the Yampa district, northwest Colorado. Ph.D. Dissertation, University of Colorado, Boulder, 675 p.

[4] Kuhn, T.S. (1970) The Structure of Scientific Revolutions. 2nd Edition, Enlarged, The University of Chicago Press, Chicago, $210 \mathrm{p}$.

[5] Clausen, E. (2020) Analyzing Anomalous Topographic Map Drainage System and Landform Evidence as a Glacial History Paradigm Problem: A Literature Review. Open Journal of Geology, 10, 1072-1090. https://doi.org/10.4236/ojg.2020.1011052

[6] Powell, J.W. (1875) Exploration of the Colorado River of the West and Its Tributaries. United States Government Printing Office, Washington DC, $291 \mathrm{p}$.

[7] Emmons, S.F. (1877) United States Geological Exploration of the 40th Parallel. Vol. 2, United States Government Printing Office, Washington DC, 921 p.

[8] White, C.A. (1889) On the Geology and Physiography of a Portion of Northwestern Colorado and Adjacent Parts of Utah and Wyoming. United States Geological Survey $9^{\text {th }}$ Annual Report, 677-712.

[9] Hancock, E.T. (1914) The History of a Portion of Yampa River, Colorado, and its Possible Bearing on that of Green River. United States Geological Survey Professional Paper 90-K, 183-189. https://doi.org/10.3133/pp90K

[10] Sears, J.D. (1924) Relations of the Browns Park Formation and the Bishop Conglomerate, and Their Role in the Origin of Green and Yampa Rivers. Bulletin of the Geological Society of America, 35, 279-304. https://doi.org/10.1130/GSAB-35-279

[11] Hunt, C.B. (1969) Geologic History of the Colorado River. In: Rabbitt, M.C., McKee, E.D., Hunt, C.B. and Leopold, L.B., Eds., The Colorado River Region and John Wesley Powell, United States Geological Survey Professional Paper 669, 59-130.

[12] Hansen, W.R. (1986) Neogene Tectonics and Geomorphology of the Eastern Uinta Mountains in Utah, Colorado, and Wyoming. United States Geological Survey Professional Paper 1356, 78 p. https://doi.org/10.3133/pp1356

[13] Aslan, A., Karlstrom, K.E., Crossey, L.J., Kelley, S., Cole, R., Lazear, G. and Darling, A. (2010) Late Cenozoic Evolution of the Colorado Rockies: Evidence for Neogene Uplift and Drainage Integration. In Morgan, L.A. and Quane, S.L., Eds., Through the Generations. Geologic and Anthropogenic Field Excursions in the Rocky Mountains from Modern to Ancient, Vol. 18, Geological Society of America, Boulder, CO, 21-54. https://doi.org/10.1130/2010.0018(02)

[14] Buffler, R.T. (2003) The Browns Park Formation in the Elkhead Region, Northwestern Colorado-South Central Wyoming: Implications for Late Cenozoic Sedimentation. In: Raynolds, G. and Flores, R.M., Eds., Cenozoic Systems of the Rocky Mountain Region, Rocky Mountain SEPM, Denver, 183-212.

[15] Larson, E.E., Ozima, M. and Bradley, W.C. (1975) Late Cenozoic Basic Volcanism in Northwestern Colorado and Its Implications Concerning Tectonism and the Origin of the Colorado River System. In: Curtis, B.F., Ed., Cenozoic History of the South Rocky Mountains, Vol. 144, Geological Society of America, Boulder, CO, 155-178. https://doi.org/10.1130/MEM144-p155

[16] Rosenberg, R., Kirby, E., Aslan, A., Karlstrom, K., Heizler, M. and Ouimet, W. (2014) Late Miocene Erosion and Evolution of Topography along the Western Slope of the Colorado Rockies. Geosphere, 10, 641-663. https://doi.org/10.1130/GES00989.1

[17] Aslan, A., Borass-Connors, M., Sprinkel, D.A., Becker, T.P., Lynds, R., Karlstrom, 
K.E. and Heizler, M. (2018) Cenozoic Collapse of the Eastern Unita Mountains and drainage Evolution of the Unita Mountains Region. Geosphere, 14, 115-140. https://doi.org/10.1130/GES01523.1

[18] Clausen, E. (2020) Topographic Map Analysis of Mountain Passes Crossing the Continental Divide between Colorado River Headwaters and North and South Platte River Headwaters to Test a New Geomorphology Paradigm, Colorado, USA. Journal of Geography and Geology, 12, 50-64. https://doi.org/10.5539/jgg.v12n1p50

[19] Clausen, E. (2019) Use of Topographic Map Evidence from Drainage Divides Surrounding Wyoming's Great Divide Basin to Compare Two Fundamentally Different Regional Geomorphology Paradigms. Earth Science Research, 9, 45-57. https://doi.org/10.5539/esr.v9n1p45

[20] Clausen, E. (2019) Use of Topographic Map Evidence to Test a Recently Proposed Regional Geomorphology Paradigm: Wind River-Sweetwater River Drainage Divide Area, Central Wyoming, USA. Open Journal of Geology, 9, 404-423.

https://doi.org/10.4236/ojg.2019.98027

[21] Clausen, E. (2021) Topographic Map Analysis of the North Platte River-South Platte River Drainage Divide Area, Western Larimer County, Colorado, USA. Earth Science Research, 10, 49-60. https://doi.org/10.5539/esr.v10n1p49

[22] Clausen, E. (2020) North Platte River-South Platte River Confluence Area Drainage System History as Determined by Topographic Map Interpretation: Western $\mathrm{Ne}$ braska, USA. Journal of Geography and Geology, 12, 28-39. https://doi.org/10.5539/jgg.v12n2p28

[23] Clausen, E (2019) Use of Stream and Dismembered Stream Valleys Now Crossing Wyoming's Northern Laramie Mountains to Test a Recently Proposed Regional Geomorphology Paradigm, USA. Open Journal of Geology, 9, 731-751. https://doi.org/10.4236/ojg.2019.911087

[24] Chamberlin, T.C. (1890) The Method of Multiple Working Hypotheses. Science, 15, 92-96. https://doi.org/10.1126/science.ns-15.366.92 